\title{
Penggunaan Sari Umbi Bawang Merah pada Pembibitan Pepaya
}

\section{Application of Shallot Bulbs Extract in Papaya Seedling}

\author{
Faryska Nur Ichsan ${ }^{1)}$, Djoko Purnomo ${ }^{2)}$, Linajanti Darsana ${ }^{2)}$
}

\begin{abstract}
People awareness toward nutritious food through the consumption of fruit is rising. Therefore, it needs the increasing of seed availability, either from the planting expansion or cultivation technology development. The productive life of papaya is around 3 years, so the rejuvenate of plant takes relatively quickly. However, the obstacle occurred comes from the adequate life of seed availability and the limitedness of homogeneous seed. Therefore, young seed forced to be used in the field will cause the growth of the plant not in unison. Moreover, it is also not profitable if it is considered from the cultivation of seedlings, since the price of the seed will be cheaper. This research aims to get papaya's seed which can grow fast and uniformly using growth stimulant substance just like gibberellins that is easy to get and cheap. The experiment studies using concentrations of union juice as the substance to soak the planting material seed of papaya before it is planted. The test of durability and germination speed toward 10 seeds on opaque paper in a petri dish germination medium which the diameter is $11,5 \mathrm{~cm}$. The experiment of seeds growth uses completely randomized design (RAL) in a factor of water treatment, the concentration of union juice is $5,10,15$, and $20 \mathrm{ml} \mathrm{I}^{-1}$, and $10 \mathrm{ppm}$ gibberellin. Every treatment (experimental unit) consists of 8 seeds planted on the traypot (combination of plastic pots, which each size about: on the surface and high $5,5 \times 5,5 \times 5,5 \mathrm{~cm}$, pots base 2,5×2,5 cm, an each traypot consists of 32 pots). Thus, there were 8 unit experiments for each traypot, and every single unit of experiments is repeated 3 times. Traypot and petri dish are put beneath the roof in the terrace protected by paranet $65 \%$ with $2,5 \times 1,5 \times 2,0 \mathrm{~m}$ (length, width, and height) in size. The union juice which is potential is used as the substitute of plant growth regulators gibberellins in papaya seedling. The response of papaya seed toward union juice with $15 \mathrm{ml} \mathrm{I}^{-1}$ concentration is equal to $10 \mathrm{ppm}$ gibberellin, occurred in germination (durability and speed of germination) and the seed growth (the root length, the stem diameter, number of leaves, and biomass weight).
\end{abstract}

Keywords : papaya, seedling, union shallot juice

\section{PENDAHULUAN}

Pepaya (Carica papaya L.) merupakan komoditas buah tropika utama, sangat bermanfaat bagi kesehatan. Pemasaran pepaya tersebar di berbagai kota di belahan dunia tidak terkecuali Indonesia. Karena kondisi lingkungan yang memadai, maka Indonesia termasuk lima besar negara produsen utama buah pepaya. Pepaya sebagai komoditas hortikultura memiliki berbagai keunggulan, seperti cepat berproduksi, berbuah sepanjang tahun, dan tidak memerlukan lahan penanaman yang luas, sehingga dapat ditanam di pekarangan. Sebagai buah tropika, pepaya bermanfaat bagi daya tahan tubuh di daerah tropis, karena kandungan vitamin, mineral, dan serat yang lengkap serta buah tidak masam. Oleh karena itu pepaya dapat dikonsumsi semua usia tanpa pengaruh pada kemasaman lambung (Sobir 2010).

Manfaat yang besar mengakibatkan permintaan buah pepaya makin tinggi sehingga terbuka luas peluang usaha. Peluang usaha dibibang budidaya pepaya sejak dari penyediaan biji bahan tanam, bibit,

\footnotetext{
1) Undergraduate Student of Study Program of Agrotechnology, Faculty of Agriculture University of Sebelas Maret (UNS) in Surakarta.

${ }^{2)}$ Lecturer of Study Program of Agrotechnology, Faculty of Agriculture University of Sebelas Maret (UNS) in Surakarta.
}

Contact Author: linayanti_darsana@yahoo.com dan sarana produksi, serta produksi. Ketersediaan bahan tanam sangat diperlukan selain untuk perluasan tanam juga karena masa produktif tanaman pepaya hanya sekitar tiga tahun, sehingga terus perlu peremajaan. Dengan demikian bibit pepaya diperlukan dalam jumlah besar dengan waktu yang relatif pendek. Bibit yang tumbuh serempak, cepat, dan sehat diperlukan dalam pertanaman pepaya. Bibit umur muda selain berakibat pada kualitas rendah dan ketidak seragaman tanaman di lapangan juga tidak menguntungkan sebagai bidang usaha karena harga jual rendah.

Secara morfologi biji pepaya belapis kulit (keputihan, lunak, dan agak bening) disebut sarkotesta. Pada sarkotesta terdapat senyawa fenolik yang menghambat perkecambahan benih (Chow dan Lin 1991), namun sarkotesta berfungsi menunda proses deteriorasi (kemunduran benih) (Sari 2005). Agar biji pepaya cepat berkecambah (biji tidak mengalami deteriorasi), sehingga bibit cepat tersedia dan tumbuh serempak dapat diusahakan menggunakan zat pengatur tumbuh. Zat pengatur tumbuh yang menginduksi perkecambahan adalah giberelin (Fosket 1994), terutama pematahan dormansi biji (Salisbury dan Ross 1992).

Untuk kalangan petani, giberelin yang tersedia (sintetis) relatif sulit diperoleh, mahal, dan perlu ketelitian tinggi dalam penggunaan. Bagi petani bermodal terbatas perlu alternatif pengganti giberelin yang mudah didapat dan selalu tersedia. Bawang merah diduga memiliki kandugan auksin 
(Ependi 2009), auksin dan giberelin (Anonim 2009). Kandungan giberelin bawang merah diuji melalui penelitian Setyowati (2004) yang menunjukkan bahwa sari umbi bawang merah mampu memacu pertumbuhan panjang akar, panjang tunas, dan jumlah tunas pada stek mawar. Demikian pula Sekta (2005), dari penelitian pada stek cabe memperoleh bahwa, penggunaan sari larutan bawang merah memberikan pengaruh nyata tehadap panjang tunas, jumlah daun, tingkat kehijauan daun, dan berat kering tunas. Ekstrak bawang merah digunakan oleh Muswita (2011) untuk meningkatkan persentase setek hidup dan jumlah akar gaharu masing-masing dengan konsentrasi 1,0 dan $0,5 \%$. Penelitian ini bertujuan memperoleh jawaban 1) apakah jus umbi bawang merah dapat berperan dalam perkecambahan dan pertumbuhan bibit pepaya serupa giberelin, 2) berapa konsentrasi jus umbi bawang merah diperlukan dalam perkecambahan dan pertumbuhan bibit pepaya. Penelitian diharapkan memperoleh jawaban sehingga bermanfaat dalam peningkatan teknologi pembibitan pepaya.

\section{METODE PENELITIAN}

Penelitian dilaksanakan pada bulan Mei sampai dengan Oktober 2013 bertempat di lokasi dengan posisi geografi $7^{\circ} 30^{\prime} 8725^{\prime \prime}$ LS dan $110^{\circ} 36^{\prime} 0967^{\prime \prime}$ BT, tinggi tempat $455 \mathrm{~m}$ dpl dan di laboratorium Fisiologi dan Bioteknologi Tanaman. Biji pepaya adalah hasil buah dari tanaman pepaya kultivar Boyolali berasal dari varietas Thailand yang sudah beradaptasi. Uji daya dan kecepatan berkecambah (terhadap 10 biji, masing-masing diulang 3 kali) menggunakan cawan petri (diameter $11,5 \mathrm{~cm}$ ) yang didalamnya terdapat kertas pastur (buram) sebagai alas biji dan penjaga kelembaban. Biji pepaya diambil dari bagian tengah buah telah masak (warna merah hampir merata) (Kamil 1979), setelah sarkotesta dihilangkan (dipilin bercampur abu dapur) kemudinan dibilas dengan air, setelah itu dikeringkan selama 2 hari di bawah sinar matahari. Biji saat akan ditanam (uji daya kecambah maupun pertumbuhan) direndam dalam larutan perlakuan selama 2 hari hingga semua biji tenggelam.

Sebagai media pembibitan adalah traypot (gabungan pot plastik, ukuran setiap pot: di permukaan dan tinggi $5,5 \times 5,5 \times 5,5 \mathrm{~cm}$, dasar pot $2,5 \times 2,5 \mathrm{~cm}$, dan setiap traypot terdiri atas $32 \mathrm{pot}$ ). Dengan demikian setiap traypot terdapat 8 satuan percobaan, setiap satuan percobaan diulang 3 kali) yang diisi tanah. Tanah media pembibitan dari jenis tanah regosol yang telah diayak (diameter ayakan 2 $\mathrm{mm}$ ) dan dicampur pupuk kandang sapi yang telah terdekomposisi (bentuk asli kotoran beserta bahan lain tidak tampak lagi), perbandingan 2:1. Pengisian tanah kedalam traypot, hingga penuh (rata di permukaan) dengan kepadatan sedang. Larutan bawang merah berasal dari $1 \mathrm{~kg}$ umbi dimasukkan dalam juicer (kapasitas $350 \mathrm{ml}$ ). Cairan hasil pengoperasian juicer (jus bawang merah) kemudian diencerkan sesuai perlakuan. Penentuan konsentrasi jus bawang merah, dilakukan penelitian pendahuluan berupa uji daya kecambah 15 biji pepaya dalam larutan dari 2 hingga $100 \%$, dan diperoleh hasil bahwa dengan konsentrasi jus bawang merah 2 dan $4 \%$ daya kecambah mencapai $80-86,67 \%$. Oleh karena itu konsentrasi jus bawang merah dalam penelitian ini berkisar 0,5 hingga $2,0 \%$.

Rancangan penelitian adalah rancangan acak lengkap (RAL) dengan faktor tunggal, satu faktor dengan perlakuan air, jus bawang merah konsentrasi $5,10,15$, dan $20 \mathrm{ml} \mathrm{I}^{-1}$, serta giberelin $10 \mathrm{ppm}$. Setiap perlakuan (satuan percobaan) terdiri atas 8 bibit yang ditanam diatas traypot. Traypot dan cawan petri diletakkan dibawah atap teras rumah dengan naungan paranet $65 \%$ berukuran $2,5 \times 1,5 \times 2,0 \mathrm{~m}$ (panjang, lebar, dan tinggi). Analisis untuk daya dan kecepatan berkecambah secara deskriptif, sedangkan untuk pertumbuhan bibit menggunakan analisis ragam, jika perbedaan nyata terjadi diteruskan dengan uji Duncan 0,95, juga uji korelasi. Pengamatan terdiri atas daya kecambah (kecambah umur 21 hari), kecepatan kecambah (kecambah umur 14 hari), panjang akar, diameter batang, tinggi bibit, karakter daun (jumlah dan luas), dan biomassa (karakter pertumbuhan diamati saat akhir penelitian, umur 48 minggu).

\section{HASIL DAN PEMBAHASAN}

\section{Perkecambahan biji}

Kecepatan berkecambah menunjukkan kemampuan biji tumbuh pada hari tertentu secara serempak. Semakin cepat biji berkecambah, semakin cepat tersedia untuk ditanam. Pada umumnya kecepatan berkecambah ditentukan berdasarkan suatu hari saat $60-70 \%$ biji sudah berkecambah. Jus bawang merah konsentrasi 15 dan $20 \mathrm{ml} \mathrm{I}^{-1}$ mengakibatkan biji berkecambah sebesar $60 \%$ sekitar 13-14 hari. Perkecambahan ini lebih cepat 3-6 hari daripada biji yang sebelumnya direndam dalam akuades atau jus bawang merah konsentrasi 5 dan 10 $\mathrm{ml} / \mathrm{l}$. Kecepatan ini sama dengan yang dicapai biji yang direndam dalam giberelin konsentrasi 10 ppm (Gambar 1).

Hasil ini menunjukkan bahwa jus bawang merah konsentrasi 15 hingga $20 \mathrm{ml} \mathrm{I}^{-1}$ memiliki kandungan giberelin setara konsentrasi $10 \mathrm{ppm}$. Kemungkinan lain adalah jus bawang merah konsentrasi 15 hingga $20 \mathrm{ml} / \mathrm{l}$ sebagai pengaktif giberelin endogen yang terdapat pada biji pepaya. Setyowati (2004) melaporkan bahwa pemberian sari umbi bawang merah mampu memicu pertumbuhan panjang akar, panjang tunas, dan jumlah tunas pada stek mawar. Giberelin pada biji mendorong pemanjangan sel sehingga radikula dapat menembus endosperm kulit biji (Salisbury dan Ross 1995). Selain itu giberelin berperan dalam fase berkecambah dan akhir fase dormansi melalui pembentukan enzim $\alpha$-amilase (Hopkins 1995), dengan istilah lain giberelin dapat menghilangkan masa dormansi biji (Gardner et. al. 1991).

Daya berkecambah biji merupakan kemampuan biji untuk tumbuh dalam jangka waktu tertentu. Daya kecambah biji digunakan sebagai indikator mutu biji sebagai bahan tanam. Untuk tanaman pepaya rentang waktu uji daya kecambah ditentukan 21 hari. Peran jus bawang merah terhadap daya kecambah 
biji pepaya belum tampak saat konsentrasi 5\% (sama besar dengan yang direndam air). Pengaruh jus bawang merah tampak setelah mencapai konsentrasi $10-20 \mathrm{ml} \mathrm{l}^{-1}$ yang meningkatkan daya kecambah antara 10 hingga 20\%. Namun peran jus bawang merah optimum adalah pada konsentrasi $15 \mathrm{ml} \mathrm{l}^{-1}$ (daya kecambah mencapai 90\%). Meskipun daya kecambah lebih rendah daripada biji yang direndam dalam giberelin 10 ppm (mencapai 100\%), penggunaan jus bawang merah untuk meningkatkan daya kecambah telah tercapai, terutama konsentrasi $15 \%$ (Gambar 1). Kecepatan berkecambah berkorelasi negatif dengan daya berkecambah ( $r=$ 0,9 ), dapat dinyatakan bahwa biji semakin cepat berkecambah (hari yang diperlukan oleh biji berkecambah semakin singkat) semakin besar daya kecambah. Giberelin embrio biji yang berkecambah diperlukan untuk sintesis $\alpha$-amilase di lapisan aleuron dalam proses hidrolisis pati dalam endosperm (Taiz dan Zieger 2010).

\section{Pertumbuhan bibit}

Saat biji berkecambah tumbuh akar, kemudian batang, dan daun. Panjang akar merupakan parameter pertumbuhan awal, sehubungan dengan aktivitas pertumbuhan biji. Akar tumbuh memanjang dalam mempersiapkan penyediaan air dan hara (Sitompul dan Guritno 1995). Jus bawang merah konsentrasi $10-20 \mathrm{ml} \mathrm{l}^{-1}$ meningkatkan panjang akar (masing-masing dengan panjang 6,7, 8,1 dan 7,8 cm). Panjang akar kecambah pada biji direndam air dan jus bawang merah konsentrasi $5 \mathrm{ml} \mathrm{l}^{-1}$ lebih rendah (5,4 dan 4,5 $\left.\mathrm{ml} \mathrm{l}^{-1}\right)$, yang tertinggi adalah akar kecambah biji yang direndam giberelin 10 ppm, namun tidak berbeda nyata dengan biji yang direndan jus bawang merah $15 \mathrm{ml} \mathrm{l}^{-1}$ (Gambar 2). Dengan demikian dari kecepatan berkecambah, daya berkecambah, hingga panjang akar, peranan jus bawang merah konsisten pada $15 \mathrm{ml} \mathrm{l}^{-1}$, yang setara dengan giberelin 10 ppm. Peranan konsentrasi beserta jumlah zat pengatur tumbuh (Omon 2002) atau substansi yang mengandung zat pengatur tumbuh untuk pertumbuhan tanaman, tidak terkecuali sistem perakaran, sangat penting.

Apakah pertumbuhan akar menunjang pertumbuhan selanjutnya, tampak pada diameter batang. Diameter batang sebagai salah satu tolok ukur pertumbuhan tanaman di atas media tanam (Ashari 1995), tampak bahwa diantara biji yang direndam jus bawang merah 10 hingga $20 \mathrm{ml} \mathrm{l}^{-1}$ dan giberelin 10 ppm tidak berbeda nyata $(0,31-0,34 \mathrm{~cm})$. Angka tersebut lebih besar daripada tanaman berasal dari biji yang direndam air dan jus bawang merah $5 \mathrm{ml}$ $\mathrm{I}^{-1}(0,3 \mathrm{~cm})$ (Gambar 2). Melalui uji korelasi pajang akar bergubungan erat (korelasi positif, $r=0,83$ ) dengan diameter batang, yang berarti panjang akar berperan dalam pertumbuhan tanaman muda. Absorpsi air dan unsur hara dilanjutkan proses fotosintesis menghasilkan asimilat yang saat perumbuhan sebagian besar terakumulasi dalam organ tanaman selain sebagai substrat respirasi. Oleh karena itu diamerter batang selalu berkaitan dengan panjang akar (Mardani 2005).
Daun sebagai organ fotosintesis tumbuh dari tunas pada buku di batang. Daun yang berkisar 6 hingga 9 helai dan berkorelasi positif dengan diameter batang $(r=0,64)$ berarti gangguan yang berarti pada pertumbuhan tidak terjadi. Jumlah daun diantara tanaman yang berasal dari biji yang direndam air dan jus bawang merah hampir sama (berkisar 6 hingga 7 helai), hanya tanaman yang berasal dari biji direndam giberelin 10 ppm, mencapai jumlah daun sekitar 9 helai (Gambar 3). Fakta menunjukkan bahwa diameter batang sekitar $0,3 \mathrm{~cm}$ pada semua perlakuan, namun jumlah daun lebih banyak pada tanaman berasal dari biji direndam giberelin 10 ppm. Dengan demikian dapat diasumsikan bahwa tanaman dari biji direndam giberelin 10 ppm memiliki buku lebih banyak karena tinggi tanaman hampir sama (data tidak tercantum). Buku lebih banyak padahal tinggi tanaman hampir sama, berarti ruas lebih pendek. Peristiwa ini kemungkinan sama dengan yang terjadi pada tanaman tebu saat suhu rendah di musim dingin (Taiz dan Zieger 2006).

Kuantitas cahaya dapat ditangkap kemudian diabsorpsi daun tergantung cahaya dan karakter daun. Salah satu karakter sebagai indikator jumlah cahaya dapat ditangkap adalah luas permukaan daun yang bila tanaman merupakan populasi dinyatakan dengan indeks luas daun (ILD), yakni perbandingan luas semua daun pada tajuk tanaman dibanding dengan luas lahan tempat tanaman tumbuh. Pembibitan tanaman dilakukan di lahan yang relatif terbatas sehingga karakter daun (luas) dinyatakan secara individual. Luas daun bibit pepaya meningkat pada tanaman yang berasal dari biji yang direndam jus bawang merah 15 dan $20 \mathrm{ml} \mathrm{I}^{-1}$, serta giberelin 10 ppm (pada tiga perlakuan tersebut tidak berbeda nyata) (Gambar 3). Luas daun menentukan sebagian besar laju fotosintesis per tanaman, oleh karena itu melalui parameter tersebut informasi tentang fotosintesis tanaman dapat diperoleh (Sitompul dan Guritno 1995). Korelasi positif antara jumlah dan luas daun relatif tinggi $(r=0,75)$. Namun, dengan jumlah daun pada bibit pepaya berasal dari biji yang direndam dalam jus bawang merah 15 dan $20 \mathrm{ml} \mathrm{l}^{-1}$ yang relatif lebih sedikit, sedangkan luas daun tidak berbeda nyata, berarti secara individual daun bibit tersebut relatif lebih luas dari pada bibit berasal dari biji direndam giberelin $10 \mathrm{ppm}$.

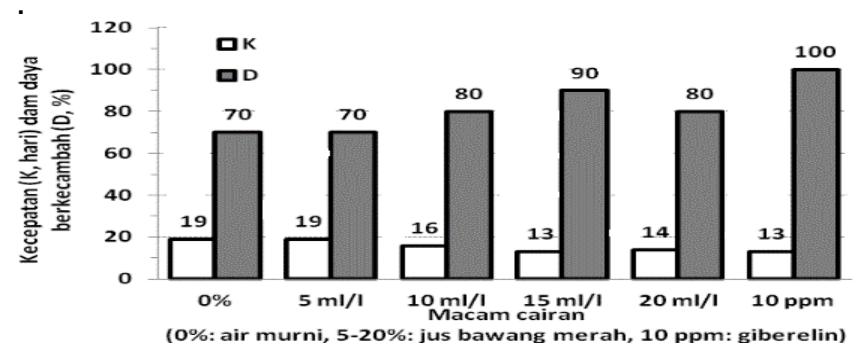

Gambar 1. Kecepatan berkecambah (pada 14 hari) dan daya berkecambah (pada 21 hari) 


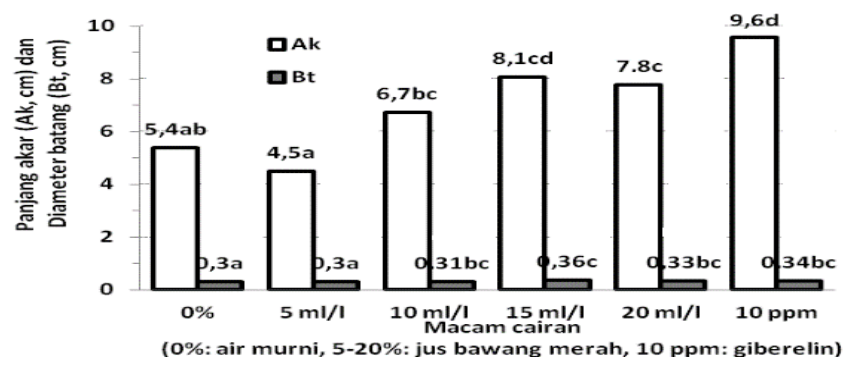

Gambar 2. Panjang akar dan diameter batang

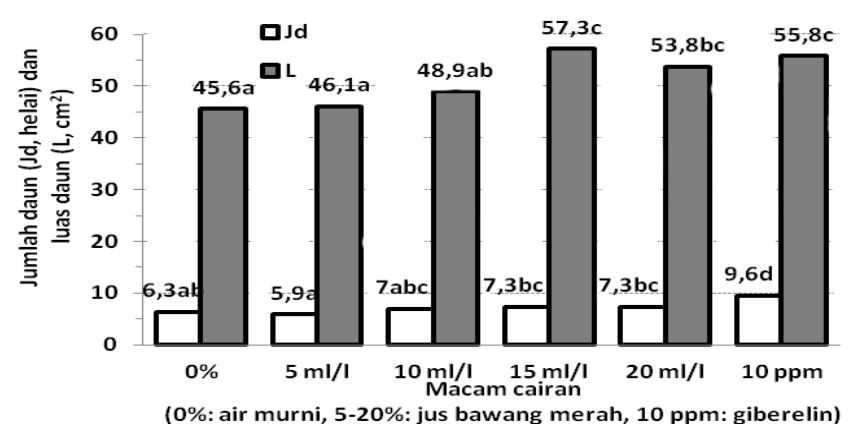

Gambar 3. Jumlah dan luas daun

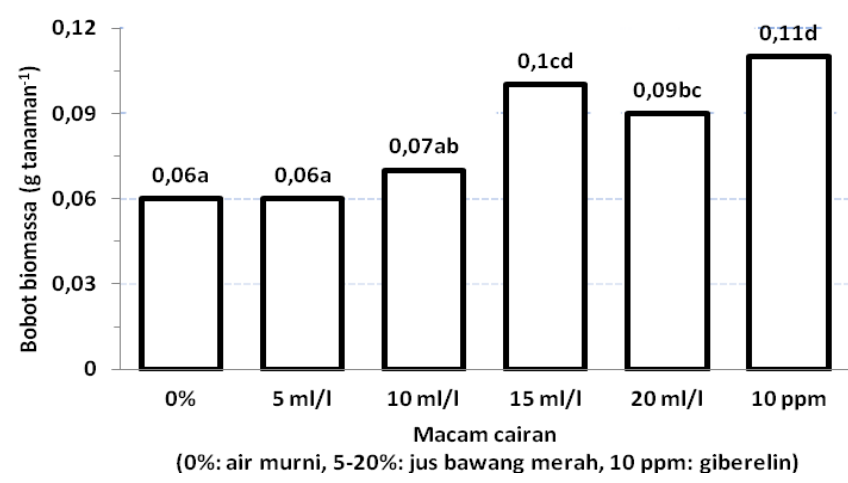

Gambar 4. Bobot biomassa

Efektifitas daun dalam mengabsorpsi cahaya sehingga laju fotosintesis tinggi terekspresikan dalam biomassa. Uji korelasi menunjukkan bahwa luas daun berhubungan sangat erat $(r=0,97)$ dengan bobot biomassa. Konsentrasi jus bawang merah 15 dan 20 $\mathrm{ml} \mathrm{I}^{-1}$, berpengaruh sangat nyata meningkatkan bobot biomassa bibit pepaya (bobot biomassa 0,90 - 0,10 g tanaman $\left.^{-1}\right)$. Peningkatan bobot biomassa juga terjadi pada bibit yang berasal dari biji dengan perendaman giberelin 10 ppm (tidak berbeda nyata dengan konsentrasi $15 \mathrm{ml} \mathrm{l}^{-1}$ ) (Gambar 4). Daun bibit yang berasal dari biji direndam pada tanaman jus bawang merah 15 dan $20 \mathrm{ml} \mathrm{I}^{-1}$ lebih luas daripada yang dari biji direndam giberelin $10 \mathrm{ppm}$, tetapi bobot biomassa lebih rendah. Ini menunjukkan bahwa efektifitas fotosintesis bibit yang berasal dari jus bawang merah 15 dan $20 \mathrm{ml} \mathrm{I}^{-1}$ lebih rendah. Daun lebih luas tetapi efektifitas fotosintesis lebih rendah berarti absorbsi cahaya dibawah optimum. Namun dapat diduga bahwa hal ini (efektifitas fotosintesis bibit yang berasal dari sari larutan bawang merah 15 dan $20 \mathrm{ml} \mathrm{l}^{-1}$ lebih rendah) bukan merupakan kendala yang berarti untuk pertumbuhan selanjutnya.

\section{KESIMPULAN DAN SARAN}

1. Jus bawang merah potensial digunakan sebagai pengganti zat pengatur tumbuh giberelin dalam pembibitan pepaya.

2. Tanggapan perkecambahan (daya dan kecepatan berkecambah) dan pertumbuhan bibit (panjang akar, diameter batang, jumlah daun, luas daun, dan bobot biomassa) pepaya terhadap jus bawang merah konsentrasi $15 \mathrm{ml} \mathrm{I}^{-1}$ setara dengan giberelin $10 \mathrm{ppm}$.

\section{DAFTAR PUSTAKA}

Ashari S. 1995. Hortikultura aspek budidaya. Jakarta (ID): UI-Press.

Chow YJ, Lin CH. 1991. p-Hydroxybenzoic acid as the major phenolic germination inhibitor of pepaya seed. Seed Sci Technol 19:167-174.

Ependi I. 2009. Zat pengatur tumbuh. http://asgarsel.blogspot.com/2009/11/zat-pengaturtumbuh. Diakses tanggal 22 Agustus 2013.

Fosket DE. 1994. Plant growth and development. A Molecular Approach. New York (NY): Academic Press.

Gardner PF, Pearce RB, Mitchell RL. 1991. Fisiologi tanaman. Jakarta (ID): Universitas Indonesia Press.

Hopkins WG. 1995. Introduction to plant physiology. New York (NY): John Wiley and Sons Inc.

Mardani DY. 2005. Pengaruh pupuk organik dan lengas tanah terhadap pertumbuhan bibit jambu Mete (Annacardium occidentale L.). Yogyakarta (ID): Fakultas Pertanian.

Muswita. 2011. Pengaruh konsentrasi bawang merah (alium cepa l.) terhadap pertumbuhan setek gaharu (Aquilaria malaccencis Oken). Skripsi. Program Studi Pendidikan Biologi, Fakultas Keguruan dan IImu Pendidikan, Universitas Jambi Kampus Pinang Masak, Mendalo Darat, Jambi.

Omon RM. 2002. Pembiakan vegetatif dengan stek batang untuk jenis shorea of plyndra pada media air. Balai Penelitian Kehutanan Samarinda.

Sari M, Murniati E, Suhartanto MR. 2005. Pengaruh sarcotesta dan pengeringan benih serta perlakuan pendahuluan terhadap viabilitas dan dormansi benih pepaya (Carica pepaya L.). Bul Agron 13(2): 23-30.

Salisbury FB, Ross CW. 1992. Plant Physiology. California (US): Wadsworth Pub. Co. $4^{\text {th }}$ ed.

Sekta ND. 2005. Aplikasi ekstrak bawang merah dan air kelapa muda pada pertumbuhan bibit stek cabe jawa (Piper retrofractum Vahl.). http://www.bdpunib.org. Diakses tanggal 22 Agustus 2013.

Setyowati T. 2004. Pengaruh ekstrak bawang merah (Allium cepa I) dan ekstrak bawang putih (Allium sativum $I$ terhadap pertumbuhan stek bunga mawar (Rosa sinensis I). JIPTUMMPP. Kota Batu. 
Sitompul SM, Guritno B. 1995. Analisis pertumbuhan tanaman. Yogyakarta (ID): Gadjah Mada University Press.

Sobir. 2010. Sukses bertanam pepaya unggul kualitas supermarket. Jakarta (ID): Agromedia.
Taiz L, Zeiger E. 2006. Plant physiology. California (US): The Benyamin/Cunmings Pub. Co.

Taiz L, Zeiger E. 2010. Plant physiology online. 4th ed. Created by Sinauer Associates Inc. 


\title{
Pengaruh Volume Pemberian Air terhadap Pertumbuhan Tiga Varietas Tomat (Lycopersicum esculentum Mill)
}

\author{
Effect Watering Volume on Growth Three Varieties of \\ Tomato (Lycopersicum esculentum Mill)
}

\author{
Roffiul Umamil Marzukoh ${ }^{1)}$, Amalia Tetrani Sakya ${ }^{2)}$, Muji Rahayu ${ }^{2)}$
}

\begin{abstract}
Tomato is one of the agriculture commodity that has many benefits. However, the production of tomato in in low land is still low so it needs effort to increase production. Issues that facing in low land cultivation are high temperature and uncertain water availibility. This study aimed to investigate the effect of watering volume on growth of tomato. This research was conducted at the Greenhouse and Laboratory of Plant Fisiology and Biotechnology, Faculty of Agriculture, Sebelas Maret University. Research was conducted from December 2012 to May 2013. This research used completely randomized factorial design with two factors of treatment, namely variety of tomato were Opal, Gondol and Mutiara and watering volume (4,4 I, 3,42 I, 2,34 I, and 1,28 I in each watering). Data were analyzed by analysis variance and continued by Duncan Multiple Range Test level of $5 \%$. The results showed that the higher of watering volume increases the growth of tomato. Plant height, number of branch, leaf area, dry weight of shoot, dry weight of root and the length of root increase with increasing watering volume. The appropriate tomato that can be developed in the various watering is Gondol.
\end{abstract}

Keywords : watering volume, tomato varieties

\section{PENDAHULUAN}

Tomat (Lycopersicum esculentum) merupakan salah satu komoditas pertanian yang sangat bermanfaat bagi tubuh karena mengandung vitamin dan mineral yang diperlukan untuk pemenuhan gizi. Vitamin A untuk mencegah xeroptalmia pada mata dan penyembuhan penyakit buta malam. Vitamin B untuk mencegah dan mengobati beri-beri, radang syaraf, dermatitis, lemah otot dan penyakit lain akibat kekurangan vitamin B. Vitamin C untuk mencegah sariawan, memelihara kesehatan gigi dan gusi serta melindungi dari penyakit lain yang disebabkan oleh kekurangan vitamin C. Besi ( $\mathrm{Fe})$ berguna untuk pembentukan sel darah merah. Kalsium (Ca) untuk pembentukan tulang dan gigi. Selain itu, buah tomat juga mengandung karbohidrat, kalori, protein, lemak dan fosfor (Depkes RI cit. MB-IPB 2010).

Permintaan pasar yang semakin meningkat terhadap produk sayuran dan manfaat yang baik dari sayuran membuat tomat menjadi pilihan utama danmenjadikan tomat sebagai komoditas yang bernilai ekonomi tinggi. Perkiraan kebutuhan tomat nasional pada tahun 2012 sebesar 920,567 ton (DBPST 2011). Berdasarkan data hasil survei produksi tanaman sayuran di Indonesia tahun 2012, produksi tomat di Indonesia pada tahun 2012 mengalami penurunan sebesar $6,35 \%$ dibandingkan produksi tomat tahun 2011. Produksi total tomat pada

\footnotetext{
1) Undergraduated student of Study of Agrotechnology, Faculty of Agriculture Sebelas Maret University in Surakarta.

2) Lecturer of Study of Agrotechnology, Faculty of Agriculture Sebelas Maret University in Surakarta.

Contact Author: sakya_at@yahoo.com
}

tahun 2011 sebesar 945,046 ton sedangkan pada tahun 2012 sebesar 893,463 ton (BPS 2012).

Lestari (2003) mengemukakan bahwa tanaman famili Solanaceae sangat rentan terhadap kekurangan dan kelebihan air selama masa pertumbuhan. Kurangnya ketersediaan air pada fase pertumbuhan dan perkembangan tanaman akan menyebabkan stres (cekaman) pada tanaman. Hal ini dapat menyebabkan produktivitas dan mutu tomat menurun. Oleh karena itu, dalam budidaya tomat perlu diketahui pemberian air yang sesuai untuk memenuhi kebutuhan air tanaman tomat agar dapat meningkatkan pertumbuhan dan produksi buah tomat. Penelitian ini bertujuan untuk mengetahui pengaruh volume pemberian air terhadap pertumbuhan dan hasil buah tomat.

\section{METODE PENELITIAN}

Penelitian dilaksanakan pada bulan Desember 2012 sampai Mei 2013 di Rumah Kaca A dan Laboratorium Fisiologi Tumbuhan dan Bioteknologi Fakultas Pertanian Universitas Sebelas Maret Surakarta. Bahan yang digunakan pada penelitian ini adalah benih tomat varietas Opal, Gondol, dan Mutiara, tanah Alfisol, pupuk kandang, pupuk urea, $\mathrm{TSP}$, pupuk $\mathrm{KCl}$. Alat yang digunakan dalam penelitian antara lain timbangan, timbangan analitik, bak persemaian, penggaris/mistar, gelas ukur, polibag, oven.

Penelitian menggunakan Ranca-ngan Acak Lengkap (RAL) dengan dua faktor perlakuan yang disusun secara faktorial. Faktor pertama adalah varietas tomat (tomat Opal, Gondol, dan Mutiara). Faktor kedua adalah volume pemberian air $(4,4 \mathrm{I}, 3,42$ I, 2,34 I, dan 1,28 I per siraman) sehingga terdapat 12 kombinasi perlakuan dan masing-masing kombinasi diulang 6 kali. Variabel yang diamati yaitu tinggi 
tanaman, jumlah cabang, luas daun, jumlah bunga, berat kering tajuk, berat kering akar, panjang akar Tabel 1. Pengaruh pemberian air dan beberapa varietas tomat terhadap tinggi tanaman pada umur 13 MST (cm)

\begin{tabular}{|c|c|c|c|c|c|}
\hline \multirow{2}{*}{ Varietas } & \multicolumn{4}{|c|}{ Volume pemberian air (liter) } & \multirow{2}{*}{ Rerata } \\
\hline & 4,4 & 3,42 & 2,34 & 1,28 & \\
\hline $\begin{array}{l}\text { Opal } \\
\text { Gondol } \\
\text { Mutiara }\end{array}$ & $\begin{array}{l}158,33^{\mathrm{d}} \\
193,33^{\mathrm{e}} \\
142,83^{\mathrm{cd}}\end{array}$ & $\begin{array}{l}160,67^{d} \\
158^{d} \\
150,67^{c d}\end{array}$ & $\begin{array}{l}138^{\mathrm{bcd}} \\
153^{\mathrm{d}} \\
130^{\mathrm{abcd}}\end{array}$ & $\begin{array}{l}100^{\mathrm{a}} \\
114,67^{\mathrm{abc}} \\
105^{\mathrm{ab}}\end{array}$ & $\begin{array}{l}139,25 \\
154,75 \\
132,125 \\
\end{array}$ \\
\hline Rerata & 164,83 & 156,45 & 140,33 & 106,56 & $(+)$ \\
\hline
\end{tabular}

Keterangan: Nilai yang diikuti huruf yang berbeda dalam satu baris dan satu kolom menunjukkan berbeda nyata pada uj Duncan taraf $5 \%$. (+): Terdapat interaksi.

dan rasio akar tajuk. Data dianalisis menggunakan analisis ragam (Anova) dengan uji $\mathrm{F}$ 5\% dan apabila terdapat beda nyata dilanjutkan uji jarak berganda (DMRT) taraf $5 \%$.

\section{HASIL DAN PEMBAHASAN}

\section{Tinggi Tanaman}

Tinggi tanaman merupakan indikator pertumbuhan yang sering diamati. Hal ini didasarkan bahwa tinggi tanaman merupakan ukuran pertumbuhan yang mudah dilihat (Sitompul dan Guritno 1995). Hasil analisis ragam menunjukkan bahwa terdapat interaksi antara volume pemberian air dan varietas tomat terhadap tinggi tanaman tomat

Ketersediaan air dalam jumlah yang cukup merupakan hal penting bagi produksi pertanian. Tabel 1 menunjukkan tomat varietas Gondol dengan penyiraman 4,4 I menghasilkan purata tinggi tanaman tertinggi dan berbeda nyata dengan perlakuan lainnya. Ketersediaan air 1,28 I pada ketiga varietas menghasilkan tinggi tanaman terendah. Hal ini selaras dengan Wahb-Allah et al. (2011), menyatakan bahwa volume pemberian air yang sedikit akan menyebabkan penurunan tinggi tanaman. Menurut Pervez et al. (2009), tanaman yang tidak tercekam menghasilkan tinggi tanaman yang paling tinggi dibandingkan yang tercekam.

Pertumbuhan tinggi tanaman dipengaruhi oleh kadar lengas tanah. Hal itu dikarenakan proses tinggi tanaman yang diawali dengan proses pembentukan tunas merupakan proses pembelahan dan pembesaran sel. Kedua proses ini dipengaruhi oleh turgor sel. Proses pembelahan dan pembesaran sel akan terjadi apabila sel mengalami turgiditas yang unsur utamanya adalah ketersediaan air (Samanhudi 2010). Adanya penurunan turgiditas dapat menghentikan perbesaran sel dan mengakibatkan pengkerdilan tanaman (Kramer 1969).

\section{Jumlah Cabang}

Jumlah cabang merupakan variabel penting dalam penelitian, sebab pada cabang akan muncul bunga sehingga apabila cabang yang terbentuk cukup banyak maka hasil akan berbanding lurus. Hasil analisis ragam menunjukkan tidak terdapat interaksi antara volume pemberian air dan varietas tomat terhadap jumlah cabang. Perlakuan pemberian air berpengaruh nyata terhadap jumlah cabang sedangkan varietas tomat tidak berpengaruh nyata terhadap jumlah cabang.
Tabel 2. Pengaruh volume pemberian air dan varietas tomat terhadap jumlah cabang tanaman pada umur 13 MST

\begin{tabular}{cc}
\hline $\begin{array}{c}\text { Volume pemberiaan air } \\
\text { (liter) }\end{array}$ & Jumlah cabang \\
\hline 1,28 & $2,11^{\mathrm{a}}$ \\
2,34 & $2,78^{\mathrm{b}}$ \\
3,42 & $3,56^{\mathrm{c}}$ \\
4,4 & $4,11^{\mathrm{c}}$ \\
\hline
\end{tabular}

Keterangan: Nilai yang diikuti huruf yang berbeda dalam satu kolom menunjukkan berbeda nyata pada uji Duncan taraf $5 \%$.

Tabel 2 menunjukkan bahwa purata jumlah cabangtertinggi pada volume pemberian air 4,4 I (4,11 cabang). Tanaman yang mengalami cekaman air akan terganggu metabolisme dan pertumbuhannya yang menyebabkan penurunan jumlah cabang. Nawangsih cit. Hartati (2000) menyebutkan bahwa tanpa adanya aliran fotosintat yang memadai akan menghambat pertumbuhan dan perkembangan tanaman menjadi dewasa, sehingga dengan kurang tersedianya air jumlah cabang tanaman tomat akan menjadi sedikit.

\section{Luas Daun}

Daun merupakan organ utama tanaman yang menyerap radiasi matahari. Hasil berat kering total merupakan hasil efiensi penyerapan dan pemanfaatan radiasi matahari yang tersedian selama pertumbuhan oleh tajuk tanaman (Goldsworthy dan Fisher 1996). Hasil analisis ragam menunjukkan bahwa terdapat interaksi antara volume pemberian air dan varietas tomat terhadap luas daun.

Tabel 3 menunjukkan bahwa tomat varietas Gondol dengan volume pemberian air 4,4 । menghasilkan purata luas daun tanaman yang tertinggi $\left(241,15 \mathrm{~cm}^{2}\right)$ dan berbeda nyata dengan perlakuan lainnya. Varietas Gondol memiliki ukuran daun lebih lebar sehingga dengan penyiraman cukup daun tanaman akan berkembang dengan maksimal. Menurut Sakya dan Rahayu (2010), tanaman dengan permukaandaun yang luas akan mengakibatkan faktor-faktor yang dibutuhkan tanaman untuk fotosintesis akan mudah terpenuhi sehingga proses fotosintesis akan dapat berjalan dengan lebih maksimal. Luas daun tanaman semakin mengecil seiring dengan pertambahan cekaman air. Ukuran luas daun yang mengecil merupakan mekanisme penghindaran tanaman menekan kehilangan air untuk 
mengurangi terjadinya transpirasi pada tanaman (Khaerana 2007).

\section{Berat Kering Tajuk, Berat Kering Akar, dan Panjang Akar}

Berat kering tumbuhan yang berupa biomassa total, sebagai manifestasi proses metabolisme yang terjadi di dalam tubuh tumbuhan. Berat kering menunjukkan produktivitas tanaman karena $90 \%$ foto sintesintat terdapat dalam bentuk berat kering (Gardner et al. 1991).

Hasil analisis ragam menunjukkan bahwa tidak terdapat interaksi antara volume pemberian air dan varietas tomat terhadap berat kering tajuk, berat kering akar, dan panjang akar tanaman tomat. Perlakuan volume pemberian air berpengaruh nyata terhadap berat kering tajuk, berat kering akar, dan panjang akar, sedangkan varietas tomat tidak berpengaruh nyata terhadap berat kering tajuk, berat kering akar, dan panjang akar tanaman tomat.
Tabel 4. menunjukkan bahwa berat kering tajuk tertinggi pada volume pemberian air 4,4 I (61,7 gram) dan berbeda nyata dengan perlakuan lainnya. Berat kering tajuk terendah pada volume pemberian air 1,28 I disebabkan oleh laju fotosintesis yang rendah akibat kekurangan air. Menurut Zgallai et al. (2006), perlakuan cekaman air pada taraf sedang sampai tinggi menghambat laju fotosintesis tanaman tomat.

Volume pemberian air 4,4 L menghasilkan purata berat kering akar tertinggi (3,06 gram), meskipun tidak beda nyata dengan volume pemberian air 3,42 I.Cekaman air akan menyebabkan transport unsur hara dalam tanaman terganggu yang berakibat pada proses biokimia (Nonami dan Boyer 1997), hal ini dicerminkan bobot kering tanaman rendah. Nahar dan Gretzmacher (2002), menyatakan bahwa pengaruh interaksi antara kekurangan air dengan kultivar tomat sangat signifikan terhadap hasil berat kering tanaman, kebanyakan kultivar kekurangan air menghasilkan berat kering yang lebih rendah.

Tabel 3. Pengaruh volume pemberian air dan varietas tomat terhadap luas daun pada umur $13 \mathrm{MST}\left(\mathrm{cm}^{2}\right)$

\begin{tabular}{llllll}
\hline \multirow{2}{*}{ Varietas } & \multicolumn{5}{c}{ Volume Pemberian Air (liter) } \\
\cline { 2 - 5 } & \multicolumn{1}{c}{4,4} & 3,42 & \multicolumn{1}{c}{ Rerata } \\
\hline Opal & $106,99 \mathrm{cde}$ & $104,44 \mathrm{cde}$ & $62,15 \mathrm{abc}$ & $57,04 \mathrm{abc}$ & 82,66 \\
Gondol & $241,15 \mathrm{f}$ & $147,65 \mathrm{e}$ & $101,03 \mathrm{cde}$ & $39,85 \mathrm{ab}$ & 132,42 \\
Mutiara & $104,58 \mathrm{cde}$ & $121,47 \mathrm{de}$ & $80,03 \mathrm{bcd}$ & $24,83 \mathrm{a}$ & 82,73 \\
Rerata & 150,9067 & 124,52 & 81,07 & 40,57 & $(+)$
\end{tabular}

Keterangan: Nilai yang diikuti huruf yang berbeda dalam satu baris dan satu kolom menunjukkan berbeda nyata pada uji Duncan taraf $5 \%$. (+): Terdapat interaksi.

Tabel 4. Pengaruh volume pemberian air dan varietas tomat terhadap berat kering (tajuk dan akar) dan panjang akar tanaman pada umur 13 MST

\begin{tabular}{cccc}
\hline $\begin{array}{c}\text { Volume Pemberian Air } \\
\text { (liter) }\end{array}$ & $\begin{array}{r}\text { Berat Kering Tajuk } \\
(\text { gram) }\end{array}$ & $\begin{array}{c}\text { Berat Kering Akar } \\
(\text { gram) }\end{array}$ & Panjang Akar $(\mathrm{cm})$ \\
\hline 1,28 & $13,76^{\mathrm{a}}$ & $1,33^{\mathrm{a}}$ & $33,78^{\mathrm{a}}$ \\
2,34 & $32,22^{\mathrm{b}}$ & $2,06^{\mathrm{b}}$ & $50,41^{\mathrm{b}}$ \\
3,42 & $48,94^{\mathrm{C}}$ & $2,88^{\mathrm{c}}$ & $51,37^{\mathrm{b}}$ \\
4,4 & $61,70^{\mathrm{d}}$ & $3,06^{\mathrm{c}}$ & $54,81^{\mathrm{b}}$ \\
\hline
\end{tabular}

Keterangan: Nilai yang diikuti huruf yang berbeda dalam satu kolom menunjukkan berbeda nyata pada uji Duncan taraf $5 \%$.

Menurut Palupi dan Yopy (2008), panjang akar berkaitan dengan ketahanan tanaman pada saat tercekam kekeringan. Tabel 4 menunjukkan bahwa purata panjang akar tertinggi pada volume pemberian air 4,4 । $(54,81 \mathrm{~cm})$. Volume pemberian air 1,28 । menghasilkan purata panjang akar terendah $(33,78$ $\mathrm{cm})$ dan berbeda nyata dengan perlakuan lainnya.

Penghambatan perkembangan akar, selain disebabkan oleh terhambatnya aktivitas sel juga disebabkan oleh daerah penetrasi akar dalam keadaan kering (kelembaban tanah rendah) sehingga akar yang baru terbentuk tidak dapat menembusnya dan akhirnya ujung akar mati. Menurut Islami dan Utomo (1995), salah satu bentuk terhambatnya pembentukan dan perkembangan sel akibat cekaman air adalah terbentuknya akar tanaman yang sedikit, ukuran kecil, dan daerah penyebaran yang relatif sempit.

\section{Rasio Akar Tajuk}

Rasio akar tajuk digunakan untuk mengetahui kemampuan tanaman dalam mempertahankan keseimbangan fungsional di lingkungan yang mengalami cekaman. Pertumbuhan tajuk lebih digalakkan apabila tersedia $\mathrm{N}$ dan air yang banyak, pertumbuhan akar lebih digalakkan apabila faktor $\mathrm{N}$ dan air terbatas (Solichatun et al. 2005). Hasil analisis ragam menunjukkan bahwa tidak terjadi interaksi antara volume pemberian air dan varietas tomat terhadap rasio akar tajuk tanaman tomat

Tabel 5 menunjukkan tidak terjadi interaksi antara volume pemberian air dan varietas tomat terhadap rasio akar tajuk tanaman tomat. Menurut Irianto et al. (2011), rasio akar tajuk pada dasarnya mencerminkan besaran alokasi fotosintat antara akar dengan tajuk, umumnya efek cekaman air dan zat penghambat tumbuh mendorong alokasi fotosintat yang lebih banyak ke akar sehingga akar berkembang dan rasio akar tajuk meningkat. Akan tetapi, dalam penelitian volume pemberian air dan varietas tomat tidak 
berpengaruh nyata terhadap rasio akar tajuk tanaman tomat.

Tabel 5. Pengaruh volume pemberian air dan varietas tomat terhadap rasio akar tajuk pada umur 13 MST (\%)

\begin{tabular}{|c|c|c|c|c|c|}
\hline \multirow[b]{2}{*}{ Varietas } & \multicolumn{4}{|c|}{ Volume Pemberiaan Air (liter) } & \multirow[b]{2}{*}{ Rerata } \\
\hline & 4,4 & 3,42 & 2,34 & 1,28 & \\
\hline Opal & 0,15 & 0,19 & 0,12 & 0,11 & $0,15^{\mathrm{a}}$ \\
\hline Gondol & 0,11 & 0,19 & 0,21 & 0,29 & $0,2^{\mathrm{a}}$ \\
\hline Mutiara & 0,27 & 0,17 & 0,08 & 0,10 & $0,16^{\mathrm{a}}$ \\
\hline Rerata & $0,18^{\mathrm{a}}$ & $0,18^{\mathrm{a}}$ & $0,14^{\mathrm{a}}$ & $0,17^{\mathrm{a}}$ & $(-)$ \\
\hline
\end{tabular}

Keterangan: Nilai yang diikuti huruf yang sama dalam satu baris dan satu kolom menunjukkan tidak berbeda nyata pada uj Duncan taraf $5 \%$. (-): Tidak terdapat interaksi.

Akar-akar tanaman tumbuh ke arah air tanah. Penanaman tanaman tomat di dalam polibag sehingga ruang tumbuh akar terbatas yang menyebabkan rhizosfer (daerah pertumbuhan akar) terbatas sehingga pertumbuhan dan perkembangan akar terbatas. Selain itu, volume tanah terbatas sehingga volume air yang tersedia untuk pertumbuhan tanaman terbatas menyebabkan pertumbuhan akar tidak optimal. Menurut Islami dan Utomo (1995), jumlah air dan hara yang diabsorbsi oleh tanaman ditentukan oleh volume tanah yang bersentuhan dengan akar.

\section{KESIMPULAN DAN SARAN}

\section{Kesimpulan}

Berdasarkan penelitian yang telah dilakukan maka dapat diambil kesimpulan sebagai berikut :

1. Tinggi tanaman, jumlah cabang, luas daun, berat kering tajuk, berat kering akar, dan panjang akar meningkat seiring meningkatnya volume pemberian air $(4,4 \mathrm{I})$.

2. Varietas tomat yang sesuai dikembangkan pada berbagai volume pemberian air adalah varietas Gondol.

\section{Saran}

Saran yang diberikan dalam penelitian ini sebagai berikut :

1. Penyiraman tanaman tomat dengan volume pemberian air 4,4 I diperlukan untuk mendapatkan pertumbuhan yang baik.

2. Perlu dilakukan penelitian lebih lanjut mengenai cekaman air dengan menggunakan varietas tomat yang lainnya.

\section{DAFTAR PUSTAKA}

Badan Pusat Statistik [BPS)]. 2012. Produksi tomat menurut Provinsi. Badan Pusat Statistik dan direktoral Jendral Hortikultura. Jakarta.

Direktorat Budidaya dan Pasca Panen Sayuran dan Tanaman Obat [DBPST]. 2011. Koordinasi penetapan pola produksi. http://ditsayur. hortikultura.deptan.go.id. Diakses 6 November 2013.

seed quality of tomato (Lycopersicon esculuntum L). Pak. J Agri Sci 46(3): 174-178.

Sakya AT, Rahayu M. 2010. Pengaruh pemberian unsur mikro besi $(\mathrm{Fe})$ terhadap kualitas anthurium. Agrosains 12(1): 29-33.
Goldsworthy PR, Fisher NM. 1996. Fisiologi tanaman budidaya tropik. Yogyakarta (ID): Gadjah Mada University Press.

Gardner FP, Pearce RB, Roger LM. 1991. Fisiologi tanaman budidaya. Jakarta (ID): UI Press.

Hartati S. 2000. Penampilan genotip tanaman tomat (Lycopersicum esculentum mill.) hasil mutasi buatan pada kondis stress air dan kondisi optimal. Agric Sci 2(2): 35-42.

Islami T, Utomo WU. 1995. Hubungan tanah, air dan tanaman. Semarang (ID): IKIP Press.

Irianto, Budiyati I, Mapegau. 2011. Pengaruh zat penghambat tumbuh cycocel dalam meningkatkan toleransi bibit manggis pada berbagai tingkat cekaman air. J Agriv 10(3): 300-308.

Khaerana. 2007. Pengaruh cekaman kekeringan dan umur panen terhadap pertumbuhan dan kandungan xanthorrizol tanaman temulawak (Curcuma xanthorrhiza Roxb). Tesis. Program Studi Agronomi Institut Pertanian Bogor.

Kramer. 1969. Plant and soil water relationship, a modem synthesis. New York (NY): Mc GrawHill Co. Ltd.

Lestari E. 2003. Simulasi potensi hasil dan pengaruh cekaman air pada tanaman kentang (Solanum tuberosum I.) di kecamatan Lembang kabupaten Bandung. Skripsi. Institut Pertanian Bogor.

MB-IPB. 2010. Export tomat. Program Pasca Sarjana Manajemen dan Bisnis Institut Pertanian Bogor.

Nahar, Gretzmacher. 2002. Effect of water stress on nutrien uptake, yield and quality of tomato (Lycopersicon esculentum Mill.) under subtropical conditions. Die Bodenkultur 53(1): 45-51.

Nonami HY, Utomo Wu, Boyer JS. 1997. Decreased growth induced water potential. Plant Physiol 114: 501- 509.

Palupi ER, Yopi D. 2008. Kajian karakter ketahanan terhadap cekaman kekeringan pada beberapa genotif kelapa sawit (Elaes guineensis Jocq). Bul Agron 36(1): 24-32.

Pervez MA, Ayub CM, Khan HA, Shahid MA, Ashraf I. 2009. Effect of drought stress on growth, yield and

Samanhudi. 2010. Pengujian cepat ketahanan tanaman sorgum manis terhadap cekaman kekeringan. Agrosains 12(1): 9-13.

Sitompul SM, Guritno B. 1995. Analisis pertumbuhan tanaman. Yogyakarta (ID): Gadjah Mada University Press. 
Solichatun, Endang A, Widya M. 2005. Pengaruh ketersediaan air terhadap pertumbuhan dan kandungan bahan aktif saponin tanaman Ginseng Jawa (Talinum paniculatum Gaertn.). Biofarmasi 3 (2): $47-51$.

Wahb-Allah MA, Alsadon AA, Ibrahim AA. 2011. Drought tolerance of several tomato genotype under greenhouse condition. World Appl Sci J 15(7): 933-940.

Zgallai H, Steppe K, Lemeur R. 2006. Effect of different level of water stress on leaf water potensial, stomatal resistance, protein and chlorophyll content and certain anti-oxidative enzymes in tomat plants. J Int Plan Biol 48(6): 679687. 